Mohsen Ghobadi ${ }^{1}$

SCIENTIFIC REVIEW ARTICLE

Faculty of Management and Economic

doi:10.5937/ekonomika1502117G

Dehaghan Branch, Islamic Azad University, Isfahan, Iran

Received: April 5, 2015

Mitra Torabi

Accepted: May 4, 2015

Department of Financial Engineering

Dehaghan Branch, Islamic Azad University, Isfahan, Iran

\title{
INVESTMENT RANKINGS BASED ON TECHNICAL ANALYSIS BY FUZZY MCDM IN TEHRAN STOCK EXCHANGE
}

\begin{abstract}
There are too many numbers of criteria for the investor to consider before making the final decision, including Overall Trend, Buying/Selling Pressure, Reward to Risk Ratio of a New Position and Potential entry levels for new long position, etc. When the investment strategies are evaluated from above aspects, it can be regarded as a fuzzy multi-criteria decision-making (FMCDM) problem. This research explains a fuzzy hierarchical analytic approach to determine the weighting of subjective judgments. In addition, it presents a non-additive fuzzy integral technique to evaluate technical analysts. Since investors cannot clearly estimate each considered criterion in terms of numerical values for the anticipated alternatives, fuzziness is considered applicable. Consequently, this research uses triangular fuzzy numbers to establish weights and anticipated achievement values. By ranking fuzzy weights and fuzzy synthetic performance values, we can determine the relative importance of criteria and decide the best strategies. We also apply what is called a fuzzy measure and non-additive fuzzy integral technique to evaluate aquatic investment. In addition, we demonstrate that the non-additive fuzzy integral is an effective evaluation and appears to be appropriate, especially when the criteria are not independent.
\end{abstract}

Key words: Investment Rankings, Technical Analysis, Fuzzy MCDM, Nonadditive fuzzy integral.

JEL classification: G11, G17, C02

\footnotetext{
${ }^{1}$ Ghobadi1989@yahoo.com

2Mtorabi2015@yahoo.com
} 


\title{
РАНГИРАҢЕ ИНВЕСТИЦИЈА НА ОСНОВУ ТЕХНИЧКЕ АНАЛИЗЕ ПО „FUZZY МСDМ“ НА ТЕХЕРАНСКОЈ БЕРЗИ
}

\begin{abstract}
Апстракт
Постоји веома велики број критеријума које инвеститор треба да размотри пре доношења коначне одлуке, укључујући и Општи тренд (Overall Trend), Куповини/продајни притисак (Buying/Selling Pressure), Награда за рацио ризика нове позииије (Reward to Risk Ratio of a New Position) и Потенцијални нивои улаза за нову дугу позииију (Potential entry levels for new long position), итд. Када се инвестиционестратегијеоцеґујунаосновунаведених аспеката, такавприступ се може сматрати „,иzzу“ мултикритеријумским одлучивањем о проблему (fuzzy multi-criteria decision-making - FMCDM). Ово истраживање објашњава „, fиzzу“ “хијерархијски аналитички приступ у одређиваюу пондера субјективног одлучивања. Поред тога, оно представља неадитивниу „,иzzу“ интегралну технику за процену техничких аналитичара. Пошто инвеститори не могу јасно проценити сваки разматрани критеријум у смислу нумеричке вредности за предвиђение алтернативе, ова техника се сматра примењивом. Сходно томе, у овом истраживаюу се користе троугаони ,, ииzу“ “ бројеви за успостављање пондера и предвиђање постигнутих вредности. Рангирањем „,иzzу“ пондера и „fиzzу“ синтетичких вредности перформанси, можемо одредити релативни значај критеријума и одлучити се за најбоље стратегије. Такође примењујемо такозвану „, ииzу“ меру и неадитивну „, изzу“ интегралну технику за процену разводюености инвестиција. Показујемо да је неадитивна „, ұzzy“ интегрална техника једна ефикасна евалуација која се чини одговарајућом нарочито када су критеријуми независни.
\end{abstract}

Кључне речи: рангирање инвестиција, техничка анализа, Fuzzу MCDM, неадитивни „,ивzу“ интеграл.

\section{Introduction}

Technical analyst, who has huge market potential, has been gaining momentum in the financial market. The complexities are numerous, and overcoming these complexities to offer profitable selections is a technical analyst challenge. It is significant that the limited number of investment funds should be efficiently allocated over many stocks. The technical analysts need to evaluate the aquatic return to reduce its risk and to find the optimal combination of investing stocks out of many feasible stocks. The purpose of the technical analyst is to minimize the risk in allocating the number of investing funds to many stocks. In a real problem, because of the limit number of funds to invest in stocks, the solution of the portfolio selection problem proposed by H. Markowitz (1952) has a tendency to increase the number of stocks selected for technical analysts. In a real investment, a portfolio manager first makes a decision on how much proportion of the investment should go to the market, and then he invests the funds to which stocks. 
After that, maximizing the technical analyst performance is the primary goal of technical analyst in a corporation. Usually, the technical analyst return reflects the profitability of a fund corporation for operating and improving. This research explores which criteria, including the overall trend; Buying/Selling Pressure; Reward to risk ratio of a new position and Potential entry levels for new long positions by taking as overall evaluation and adopting the financial rations as evaluation criteria, can lead to high profitability. The profitability is evaluated by fuzzy multi-criteria decision-making (FMCDM), this information could supports analysts' decision- making.

We use trading prices and statistic data to evaluate the sub criteria. The trading price analysis, which is used to evaluate profitability, involves ratio analysis, trend analysis. The ratio analysis provides a basis for a company to compare with other companies in the same industry. The trend analysis evaluates trends in the company financial position over time. Several alternative strategies have to be considered and evaluated in terms of many different criteria consequenceing in a vast body of data that are often inaccurate or uncertain. Therefore, the purpose of this article is to improve an empirically based framework for formulating and selecting a technical analyst strategy. We propose a hierarchical Fuzzy Multi-Criteria Decision-Making (FMCDM) framework, where we combine AHP and fuzzy measure techniques in order to determine the relative weights of each criterion. The proposed strategies are then ranked using the fuzzy integral technique. To demonstrate the validity of this technique, an illustrative case is provided. The consequences explain the strategies that were adopted by this have proven to be very profitable in performance. This also proves the effectiveness of the approach proposed by this research.

In real world systems, the decision-making problems are very often uncertain or vague in a number of ways. Due to lack of information, the future state of the system might not be known completely. This type of uncertainty has long been handled appropriately by probability theory and statistics. However, in many areas of daily life, such as technical analyst, stock, debt, derivate and others, human judgment, evaluation, and decisions often employ natural language to express thinking and subjective perception. In these natural languages, the meaning of words is often vague, the meaning of a word might be well defined, but when using the word as a label for a set, the boundaries within which objects do or do not belong to the set become fuzzy or vague. Furthermore, human judgment of events may be significantly different based on individuals' subjective perceptions or personality, even using the same words. Fuzzy numbers are introduced to appropriately express linguistic variables. We will provide a clearer description of linguistic expression with fuzzy scale in a later section.

In this research, the fuzzy hierarchical analytic approach was used to determine the weights of criterias for subjective judgment, and a non-additive integral technique was utilized to evaluate the performance of investment strategies for technical analysts. Traditionally, researchers have used additive techniques to evaluate the synthetic performance of each criterion. In this article, we demonstrate that the non-additive fuzzy integral is a good means of evaluation and appears to be more appropriate, especially when the criteria are not independent situations. The conceptual investment of technical analysts is discussed in the next section, and the fuzzy hierarchical analytic approach and non-additive fuzzy integral evaluation process for multi-criteria decision-making $(\mathrm{MCDM})$ problem are derived in the subsequent section. Then an illustrative example 
is presented, applying the MCDM techniques for aquatic investment processors, after which we discuss and illustrate how the MCDM techniques in this research are effective. Finally, the conclusions are presented.

Technical Analysis is the forecasting of future financial price movements based on an examination of past price movements. Like weather forecasting, technical analysis does not consequence in absolute predictions about the future. Instead, technical analysis can help investors anticipate what is "likely" to happen to prices over time. Technical analysis uses a wide variety of charts that show price over time. Technical analysis is applicable to stocks, indices, commodities, futures or any tradable instrument where the price is influenced by the forces of supply and demand. Price refers to any combination of the open, high, low, or closes for a given security over a specific period. The period can be based on intraday (1-minute, 5-minutes, 10-minutes, 15-minutes, 30-minutes or hourly), daily, weekly or monthly price data and last a few hours or many years. In addition, some technical analysts include volume or open interest figures with their study of price action. At the turn of the century, the Dow Theory laid the foundations for what was later to become modern technical analysis. Dow Theory was not presented as one complete amalgamation, but rather pieced together from the writings of Charles Dow over several years. Of the many theorems put forth by Dow, three stand out:

- Price Discounts Everything,

- Price Movements Are Not Totally Random,

- "What" Is More Important than "Why".

Ghobadi (2014) test the Profitability of Technical Analysis Indicators to Earn Abnormal Returns in International Exchange Markets from 2008 through 2013. They conclude that the positive returns according to technical analysis indicator returns and these returns is significantly more than the London Interbank Offered Rate. They observe that the Stochastic Oscillator, Relative Strength Index, Money Flow Index, Commodity Channel Index, Simple Moving Average indicators produces the best consequences, followed by the London Interbank Offered Rate.

Manzur and Chew (2002) test the performance of the moving average method and the Relative Strength Index (RSI), a common counter-trend indicator, on the Singapore STII from 1974 through 1994. They conclude that technical indicators can play a useful role in the timing of stock market entry and exits. They observe that the single moving average produces the best consequences, followed by the dual moving average and the RSI. They note that technical analysis give returns more attractive to the trading members of the stock exchange since transaction costs may tend substantially lower the gains.

Fama (1960) developed this concept into three forms of market efficiency, or the market responds to given information set. Empirical research of weak- form efficiency of the market categorized as the tests of trading strategies using historical data. These statistical tests examine the correlations between historical price changes and run testing.

Ben R Marshall and Jared M. Cahan (2006) evaluated the profitability of CRISMA technical trading system. They collect information of companies on the CRSP database in the period of January1, 1976 to December 31, 2003 including 200 days of past closing prices and 20 days of past volume. They examine both long and short CRISMA filter rules in this study and found that even the system generates some profit but not consistently. 
Traditional AHP is assumed that there is no interaction between any two criteria within the same hierarchy. However, a criterion is inevitably correlated to another one with the degrees in reality. In 1974, Sugeno introduced the concept of fuzzy measure and fuzzy integral, generalizing the usual definition of a measure by replacing the usual additive property with a weak requirement, i.e. the monotonic property with respect to set inclusion. In this section, we give a brief to some notions of the theory of fuzzy measure and fuzzy integral.

\section{General fuzzy measure}

The fuzzy measure is a measure for representing the membership degree of an object in candidate sets. It assigns a value to each crisp set in the universal set and signifies the degree of evidence or belief of that element's membership in the set. Let $X$ be a universal set. A fuzzy measure is then defined by the following function $g: \aleph \rightarrow$ $[0,1]$

That assigns each crisp subset of $X$ a number in the unit interval $[0,1]$. The definition of function $g$ is the power set $\aleph$. When a number is assigned to a subset of $X$, $A \in \aleph, g(A)$, this represents the degree of available evidence or the subject's belief that a given element in $X$ belongs to the subset $A$. This particular element is most likely found in the subset assigned the highest value.

In order to quantify a fuzzy measure, function $g$ needs to conform to several properties. Normally function $g$ is assumed to meet the axiom of the probability theory, which is a probability theory measurement. Nevertheless, actual practice sometimes produces a consequence against the assumption. This is why the fuzzy measure should be defined by weaker axioms. The probability measure will also become a special type of fuzzy measure. The axioms of the fuzzy measures include:

(1.) $g(\phi)=0, g(X)=1$ (boundary conditions);

(2.) $\forall A, B \in \aleph$, if $A \subseteq B$ then $g(A) \beta g(B)$ (monotonicity).

Once the universal set is infinite, it is required to add continuous axioms (Klir and Folger, 1998).

Certainly, the elements in question are not within the empty set but within the universal set, regardless of the number of evidence from the boundary conditions in Axiom 1.

The fuzzy measure is often defined with an even more general function:

$g: \beta \rightarrow[0,1]$

where $\beta \subset \aleph$ so that:

1. $\phi \in \beta$ and $X \in \underline{\beta}$;

2. if $A \in \beta$, then $\bar{A} \in \beta$

3. $\beta$ is closed under the operation of set function; i.e., if $A \in \beta$ and $B \in \beta$, then $A \cup B \beta \beta$.

The set $\beta$ is usually called the Borel field. The triple $(X, \beta g)$ is called a fuzzy measure space if $g$ is a fuzzy measure on a measurable space $(X, \beta)$. 
It is sufficient to consider the finite set in actual practice. Let $X$ is a finite criterion set, $X=\left\{x_{1}, x_{2}, . ., x_{n}\right\}$ and the power set $\aleph$ be a class of all of the subsets of $X$. It can be noted that $g\left(\left\{x_{i}\right\}\right)$ for a subset with a single element, $x_{i}$ is called a fuzzy density. In the following paragraph, we use $g_{i}$ to represent $g\left(\left\{x_{i}\right\}\right)$.

The term "general fuzzy measure" is used to designate a fuzzy measure that is only required to satisfy the boundary condition and monotonic to differentiate the $\lambda$-fuzzy measure, $F$-additive measure, and classical probability measure.

\section{$\lambda$ - Fuzzy measure}

The specification for general fuzzy measures requires the values of a fuzzy measure for all subsets in $X$. Sugeno and Terano have improved the $\lambda$-additive axiom (Sugeno and Terano, 1997) in order to reduce the difficulty of collecting information. Let $(X, \beta, g)$ be a fuzzy measure space: $\lambda \in(-1, \infty)$. if $A \in \beta, B \in \beta$; and $A \cap B=\phi$, and

$$
g(A \cup B)=g(A)+g(B)+\lambda g(A) g(B)
$$

If this holds, then fuzzy measure $g$ is $\lambda$-additive. This kind of fuzzy measure is named $\lambda$ fuzzy measure, or the Sugeno measure. In this research we denote this $\lambda$-fuzzy measure by $\lambda$ to differentiate from other fuzzy measures. Based on the axioms above, the $\lambda$-fuzzy measure of the finite set can be derived from fuzzy densities, as indicated in the following equation:

$$
g_{\lambda}\left(\left\{x_{1}, x_{2}\right\}\right)=g_{1}+g_{2}+\lambda g_{1} g_{2}
$$

where $g_{1}, g_{2}$ represents the fuzzy density.

Let set $X=\left\{x_{1}, x_{2}, . ., x_{n}\right\}$ and the density of fuzzy measure $g_{i}=g_{\lambda}\left(\left\{x_{i}\right\}\right)$, which can be formulated as follows:

$$
g_{\lambda}\left(\left\{x_{1}, x_{2}, \ldots, x_{n}\right\}\right)=\sum_{i=1}^{n} g_{i}+\lambda \sum_{i_{1}=1}^{n-1} \sum_{i_{2}=i_{1}+1}^{n} g_{i_{1}} g_{i_{2}}+\cdots+\lambda^{n-1} g_{1} g_{2} \cdots g_{n}
$$

For an evaluation case with two criteria, $A$ and $B$, there are three cases based on the above properties.

Case 1: if $\lambda>0$, i.e. $g_{\lambda}(A \cup B)>g_{\lambda}(A)+g_{\lambda}(B)$, implying that $A$ and $B$ have a multiplicative effect.

Case 2: if $\lambda=0$, i.e. $g_{\lambda}(A \cup B)=g_{\lambda}(A)+g_{\lambda}(B)$, implying that $A$ and $B$ have an additive effect.

Case 3: if $\lambda<0$, i.e. $g_{\lambda}(A \cup B)<g_{\lambda}(A)+g_{\lambda}(B)$, implying that $A$ and $B$ have a substitutive effect.

The fuzzy measure is often used with the fuzzy integral for aggregating information evaluation by considering the influence of the substitutive and multiplication effect among all criteria. 


\section{Fuzzy Integral}

In a fuzzy measure $\operatorname{space}(X, \beta, g)$, let $h$ be a measurable set function defined in the fuzzy measurable space. Then the definition of the fuzzy integral of $h$ over $A$ with respect to $g$ is

$$
\int_{A} h(x) d g=\sup _{\alpha \in[0,1]}\left[\alpha \wedge g\left(A \cap H_{\alpha}\right)\right.
$$

where $H_{\alpha}=\{x \mid h(\mathrm{x}) \geq \alpha\} . A$ is the domain of the fuzzy integral. When $A=X$, then $A$ can be taken out.

Next, the fuzzy integral calculation is explaind in the following. For the sake of simplification, consider a fuzzy measure $g$ of $(X, \aleph)$ where $X$ is a finite set. Let $h: x \rightarrow[0,1]$ and assume without loss of generality that the function $\boldsymbol{J}$ is monotonically decreased with respect to $j$, i.e., $h\left(x_{1}\right) \geq h\left(x_{2}\right) \geq \cdots \geq h\left(x_{n}\right)$. To achieve this, the elements in $X$ can be renumbered. With this, we then have

$$
\int h(x) d g=\vee_{i=1}^{n}\left[f\left(x_{i}\right) \wedge g\left(x_{i}\right)\right]
$$

where $X_{i}=\left\{x_{1}, x_{2}, \cdots, x_{i}\right\}, i=1,2, \cdots n$.

In practice, $h$ is the evaluated performance on a particular criterion for the alternatives, and $g$ represents the weight of each criterion. The fuzzy integral of $h$ with respect to $g$ gives the overall evaluation of the alternative. In addition, we can use the same fuzzy measure using Choquet's integral, defined as follows (Murofushi and Sugeno, 1991):

$$
\int h d g=h\left(x_{n}\right) g\left(X_{n}\right)+\left[h\left(x_{n-1}\right)-h\left(x_{n}\right)\right] g\left(X_{n-1}\right)+\cdots+\left[h\left(x_{1}\right)-h\left(x_{2}\right)\right] g\left(X_{1}\right)
$$

The fuzzy integral model can be used in a nonlinear situation since it does not need to assume the independence of each criterion.

\section{Evaluation Model for Prioritizing the technical analysts strategy}

This study utilized the PATTERN (Planning Assistance through Technical Evaluation of Relevance Number) technique (NASA, 1965, 1966; Tang, 1999; Tzeng, 1977; Tzeng and Shiau, 1987) to build up a hierarchical system for evaluating technical analysts strategies. Its analytical procedures stem from three steps: (i) aspects, (ii) issues, and (iii) strategies. In this section, we focus on scenario writings and building relevance trees. Scenario writing is based on determining the habitual domain (Yu, 1985, 1990, 1995) , i.e., past problem understanding, personal experience, knowledge, and information derived from brainstorming techniques so as to determine the factors affecting the profitable selection of technical analysts capability. We consider the problems from four aspects: (1) Overall trend (2) Buying/Selling Pressure (3) Reward to risk ratio of a new position (4) Potential entry levels for new long position. In addition, the technical analysts with investment model classified as S1: Asset Allocation model; 
S2: Aggressive Increase model; S3: Equity Income model; S4: Increase model; S5: Increase Income model. Based on a review of the literature, personal experience, and interviews with senior technical analysts, relevance trees are used to create hierarchical strategies for improving the optimal selection strategy of technical analysts.

Minimum risk or maximum return is usually used as the only measurement index in traditional evaluation techniques. Within a dynamic and diversified decision-making environment, this approach may neglect too much valuable information in the process. Hence, we propose a FMCDM technique to evaluate the hierarchy system for selecting strategies. In addition, the issues in the investment process are sometimes vague. When this occurs, the investment process becomes ambiguous and subjective for the investor. The evaluation is conducted in an uncertain, fuzzy situation and to what extent vague criteria are realized by research is unknown (Tang and Tzeng 1999;Chiou and Tzeng, 2002). Evaluation in an uncertain, fuzzy situation applies to the formulation of technical analysts strategies as well. We have chosen a fuzzy multiple criteria evaluation technique for selecting and prioritizing the technical analysts' strategies to optimize the real scenarios faced by manager or investors.

Bellman and Zadeh (1970) were the first to study the decision-making problem in a fuzzy environment and initiated FMCDM. In this study, we use this technique to evaluate various technical analysts' strategies and rank them by their performance. The following subsection explains the technique of FMCDM.

\section{Fuzzy weights for the hierarchy process}

An evaluator always perceives the weight of a hierarchy subjectively. Therefore, to consider the uncertain, interactive effects coming from other criteria when calculating the weight of a specified criterion, we have used fuzzy weights of criteria.

Buckley (1985) was the first to investigate fuzzy weights and fuzzy utility for AHP techniques, extending AHP by geometric means technique to derive the fuzzy weights.

The fuzzy weights $\tilde{w}_{j}$ corresponding to each criterion is as follows:

$\mathrm{Wi}=\mathrm{r}^{\mathrm{J}}$

$$
\widetilde{w_{j}}=\widetilde{r}_{j} \times\left(\widetilde{r_{1}}+\cdots+\widetilde{r_{m}}\right)^{-1}
$$

Where $\tilde{r}_{i}$ is the geometric mean of each row of the AHP reciprocal matrix?

$$
\widetilde{r}_{j}=\left(\tilde{a}_{j}, \ldots \times \tilde{a}_{j m}\right)^{1 / m}
$$

The evaluators were asked to make subjective judgments using linguistic variable measurement to demonstrate the criteria performance with expressions of effectiveness ranging from "very high", "high", "fair", "low", to "very low". Each linguistic variable was indicated using a Triangular Fuzzy Number (TFN) with a range from 0 to 100. Let $\tilde{E}_{i j}^{k}$ indicate the fuzzy performance value in terms of evaluator $k$ toward strategy $i$ under criteria $j$ and the performance of the criteria is represented by the $S$, then,

$$
\tilde{E}_{i j}^{k}=\left(L \tilde{E}_{i j}^{k}, M \tilde{E}_{i j}^{k}, U \tilde{E}_{i j}^{k}\right), j \in S
$$

In this study, we used the notion of average value to consolidate the fuzzy judgment value of $m$ evaluators, i.e., 


$$
\tilde{E}_{i j}^{k}=(1 / \mathrm{m}) /\left(\tilde{E}_{i j}^{1}+\tilde{E}_{i j}^{2}+\cdots+\tilde{E}_{i j}^{m}\right)
$$

The sign denotes fuzzy multiplication and the sign $\oplus$ denotes fuzzy addition. $\tilde{E}_{i j}^{k}$ is the average fuzzy number from the judgment of the decision-maker. It can be represented using a triangular fuzzy number as follows:

$$
\tilde{E}_{i j}^{k}=\left(L \tilde{E}_{i j}^{k}, M \tilde{E}_{i j}^{k}, U \tilde{E}_{i j}^{k}\right)
$$

where,

$$
\begin{aligned}
& L \widetilde{E}_{i j}^{k}=(1 / m) \square\left(\sum_{k=1}^{m} L \widetilde{E}_{i j}^{k}\right) \\
& M \tilde{E}_{i j}^{k}=(1 / m) \square\left(\sum_{k=1}^{m} M \widetilde{E}_{i j}^{k}\right) \\
& U \tilde{E}_{i j}^{k}=(1 / m) \square\left(\sum_{k=1}^{m} U \tilde{E}_{i j}^{k}\right)
\end{aligned}
$$

The preceding end value may be solved using the technique introduced by Buckly (1985) or by Chiou and Tzeng. (2002).

\section{Empirical Study and Discussions}

In order to demonstrate the practicality of our proposed technique of enhancing the performance of technical analysts, we conducted an empirical study based on 30 valid samples from 12 iranian technical analyst companies and 8 research institutes and universities. The majority of the respondents were portfolio analysts who are responsible for financial or general management. The technical analysts' strategy selection process is examined below.

\section{Evaluating the weights of issues}

By using the fuzzy AHP technique, the weights of the issues and aspects were found and are illustration in Table 1.

Table 1 The weights of issues for evaluating the technical analysts

\begin{tabular}{|c|c|c|}
\hline Aspects/issues & Local Weights & BNP of overall weight \\
\hline Overall trend & $(0.2360 .4270 .719)$ & 0.461 \\
\hline Keltner Channels & $(0.1140 .1970 .359)$ & 0.233 \\
\hline Bollinger Bands & $(0.2630 .4370 .729)$ & 0.476 \\
\hline Moving Averages & $(0.1300 .2420 .432)$ & 0.268 \\
\hline Price Channels & $(0.0660 .1240 .226)$ & 0.139 \\
\hline Buying/Selling Pressure & $\mathbf{( 0 . 2 1 8 ~ 0 . 3 5 3 ~ 0 . 5 9 2 )}$ & 0.388 \\
\hline
\end{tabular}




\begin{tabular}{|c|l|l|}
\hline Rate of Change & $(0.1190 .2110 .368)$ & 0.232 \\
\hline Relative Strength Index & $(0.0810 .1430 .257)$ & 0.160 \\
\hline Stochastic RSI & $(0.0390 .0620 .110)$ & 0.070 \\
\hline Vortex Indicator & $(0.0970 .1720 .323)$ & 0.197 \\
\hline $\begin{array}{c}\text { Reward to risk ratio of a } \\
\text { new position }\end{array}$ & $\mathbf{( 0 . 0 9 0 ~ 0 . 1 4 3 ~ 0 . 2 4 4 )}$ & 0.159 \\
\hline Decision Point Rydex Ratio & $(0.2070 .3230 .522)$ & 0.351 \\
\hline High-Low Index & $(0.0870 .1290 .218)$ & 0.147 \\
\hline Volatility Index & $(0.3350 .5480 .851)$ & 0.578 \\
\hline $\begin{array}{c}\text { Potential entry levels for } \\
\text { new long position }\end{array}$ & $\mathbf{( 0 . 0 4 9 ~ 0 . 0 7 6 ~ 0 . 1 3 3 )}$ & 0.086 \\
\hline Standard Deviation & $(0.1300 .2690 .452)$ & 0.284 \\
\hline Money Flow Index & $(0.0810 .1380 .270)$ & 0.163 \\
\hline Force Index & $(0.2530 .4390 .776)$ & 0.489 \\
\hline Mass Index & $(0.0950 .1540 .292)$ & 0.180 \\
\hline
\end{tabular}

\section{Estimating the performance matrix}

In this study, the evaluators define their individual range for the linguistic variables employed in this study based on their judgments within the range from 0-100. The fuzzy judgment values of different evaluators regarding the same evaluation criteria are averaged. In general, fuzzy addition and multiplication were used to retrieve the average fuzzy numbers for the performance values under each criterion indicated by the evaluators for technical analysts' strategy.

Table 2 The evaluation consequences of technical analysts'strategy

\begin{tabular}{|l|l|}
\hline \multicolumn{2}{|c|}{ Technical analysts' strategy ranking } \\
\hline \multicolumn{1}{|c|}{ SAW } & $\mathrm{S} 2 \succ \mathrm{S} 4 \succ \mathrm{S} 3 \succ \mathrm{S} 1$ \\
\hline$\lambda=1$ & $\mathrm{~S} 2 \succ \mathrm{S} 4 \succ \mathrm{S} 3 \succ \mathrm{S} 1$ \\
\hline$\lambda=2$ & $\mathrm{~S} 4 \succ \mathrm{S} 3 \succ \mathrm{S} 2 \succ \mathrm{S} 1$ \\
\hline$\lambda=3$ & $\mathrm{~S} 4 \succ \mathrm{S} 2 \succ \mathrm{S} 3 \succ \mathrm{S} 1$ \\
\hline$\lambda=4$ OR MORE & $\mathrm{S} 4 \succ \mathrm{S} 1 \succ \mathrm{S} 2 \succ \mathrm{S} 3$ \\
\hline$\lambda:$ & \\
\hline & Number of Technical Analysis Strategies Criteria in Each Time for Trading \\
\hline $\begin{array}{l}\text { Where: } \\
\text { S1: Overall trend } \\
\text { S2: Buying/Selling Pressure } \\
\text { S3: Reward to risk ratio of a new position } \\
\text { S4: Potential entry levels for new long position }\end{array}$ \\
\hline
\end{tabular}


Table 3 The synthetic performance of technical analysts'strategy

\begin{tabular}{|c|c|c|c|c|c|}
\hline$\lambda$ & 1 & 2 & 3 & 4 OR MORE & SAW \\
\hline S1 & 0.380 & 0.520 & 0.290 & 0.298 & 0.372 \\
\hline S2 & 0.600 & 0.970 & 0.312 & 0.309 & 0.548 \\
\hline S3 & 0.450 & 0.670 & 0.319 & 0.313 & 0.437 \\
\hline S4 & 0.550 & 0.850 & 0.317 & 0.311 & 0.508 \\
\hline
\end{tabular}

\section{Results and Conclusion}

The empirical evidence in this research indicates that the weight of criteria such as the overall trend (0.372), Buying/Selling Pressure (0.548), Reward to risk ratio of a new position (0.437) and Potential entry levels for new long position (0.508). So the 'Buying/Selling Pressure' was the most significant factor to influence the performance of a technical analyst, next was the 'Potential entry levels for new long position'. Some econometric techniques are improved to simultaneously estimate the magnitudes of these strategies performance evaluation measures. The consequences illustrate that technical analysts are on average with positive security selection and overall trend ability. Therefore, the technical analysts should enhance the ability of an overall trend, the performance of technical analysts can be better. The fuzzy synthetic performance of each alternative using different $\lambda$ is as illustrated in Table 2 and Table 3. In table 2, our empirical consequences illustrate that when $\lambda>1$ the consequences illustrate that S2 "Buying/Selling Pressure" was the most significant strategy. In addition, S4, "Increase model" was selected as the second most significant strategy. When $\lambda>2$ the consequences illustrate that S4, "Buying/Selling Pressure " was the most significant strategy regardless of the variation of $\lambda$. Moreover, S3, "Reward to risk ratio of a new position" was selected as the second most significant strategy. When $\lambda>3$, S2 replaces S3, becoming the number 2 ranking. Nevertheless, $\lambda>4$ OR MORE, S1 replaces S2 and S3, becoming the number 2 ranking. We can infer that the asset allocation model more efficiency when the multiplicative effect exists. From Table 3 , we know that when $\lambda$ was bigger, the synthetic performance was bigger too. Therefore, these consequences implied that technical analysts have no multiplicative effect. Therefore, from investment model an average illustrates that the Buying/Selling Pressure has the largest maximum performance, but it also has the largest deviation in performance. In other word, the more Pressure the markets are, the more volatility of the market performance will be. However, the overall trend has the smallest expected performance. Next was Reward to risk ratio of a new position.

\section{Discussions and implications}

The technical analyst is moving rapidly towards financial market improvement in response to increasing market demand. The traditional quantity technique does not solve the complex problems of technical analyst improvement. Therefore, what is needed is a useful and applicable strategy that addresses the issues of improving technical analysts. 
This study addressed this issue in a more rational and objective fashion by using a FMCDM technique to achieve this goal.

Few studies have addressed technical analyst related strategic planning. Providing that this is a first attempt to formally model the formulation process for a technical analyst's strategy using FMCDM, we have the confidence that the analysis here is a significant theoretical contribution to the literature, and will help to establish the groundwork for future research. Even though we are dedicated to setting up the model as completely as possible, there are additional criteria and techniques that could be adopted and added in future research. In the meantime, we should also begin to investigate how to execute several strategies simultaneously in order to achieve the best performance of technical analyst under the constraint of resources. This study focuses on providing a technical analysts strategy for the holding companies, so that they may be profitable in their decision-making. Our empirical study demonstrates the validity of this technique. In this study, the technical analysts' strategy stems from four aspects: overall trend, Buying/Selling Pressure, Reward to risk ratio of a new position as well as Potential entry levels for new long positions. The related issues, evaluation criteria and strategies are defined in this research. Technical analysts have difficulty in utilizing the proper strategy. The major reasons are the uncertain and dynamic environment and numerous criteria that they are facing. Analysts are hence overwhelmed by this vague scenario and do not make proper decisions or allocate resources efficiently. The hierarchical technique guides the manager how to select the model of technical analysts in the uncertainty environment. With the help of this model, analysts can employ different experts to conduct the same proposed procedures and select the best investment alternative. The subjective judgment and risks of making wrong decisions is then minimized. In addition, this technique can be applied to solve different kinds of problems by modifying the constructs of the hierarchy trees and finding the appropriate solution.

\section{References}

Rahimipoor (2012), A Comparative Study of Bankruptcy Prediction Models of Fulmer and Springate in Accepted Companies in Tehran Stock Exchange, Caspian Journal of Applied Sciences Research, 1(13), 76-81.

Chan, F. T., \& Chan, H. K. (2005). Design of a PCB plant with expert system and simulation approach. Expert Systems with Applications, 28(3), 409-423.

Chen, Y.W. Tzeng, G.H. (2001), Using fuzzy integral for evaluating subjectively perceived travel cost in a traffic assignment model, European Journal of Operation Research, 130(3): 653-664.

Chenard, J. S., Chu, C. Y., Žilić, Ž., \& Popović, M. (2005, June). Design methodology for wireless nodes with printed antennas. In Proceedings of the 42nd annual Design Automation Conference (291-296). ACM.

Chiou, H.K. Tzeng, G.H. (2002), Fuzzy multi-criteria decision making approach to analysis and evaluation of green engineering for industry, Environmental Management, 30(6): 816-830.

Chiou, H.K. Tzeng, G.H. (2002), Fuzzy multicriteria decision making approach to analysis and valuation of green engineering for industry, Environmental Management, 30(6): 816-830. 
Elleuch, J., \& Trabelsi, L. (2009). Fundamental analysis strategy and the prediction of stock returns. International Research Journal of Finance and Economics, 30(1), 95-107.

Ghobadi, M., \& Abdolbaghi, A. (2014). ), Profitability of technical analysis indicators to earn abnormal returns in international exchange markets. ISJ Theoretical \& Applied Science, 11(19), 20-26.

Ghobadi, (2014), Profitability of Technical Analysis Strategy to Earn Abnormal Returns in Tehran Stock Exchange (2007-2013), M.Sc. Thesis, Islamic Azad University, Dehaghan Branch, Iran.

Hassanmirza, (2013), Does Investor Protection Affect Managements, Decision to Pay Dividend? Evidence from South Asia, Caspian Journal of Applied Sciences Research 2(11), pp. 26-38.

Liu, S. T., \& Wang, R. T. (2009). Efficiency measures of PCB manufacturing firms using relational two-stage data envelopment analysis. Expert Systems with Applications, 36(3), 4935-4939.

Lütkepohl, H., \& Krätzig, M. (2004). Applied time series econometrics. Cambridge University Press.

Mark Andrew Lim (2014), A Handbook of Technical Analysis: The Practitioner's Comprehensive Guide to Technical Analysis, Wiley.

Aderhold, R., Cumming, C., \& Harwood, A. (1988). International linkages among equities markets and the October 1987 market break. Quarterly Review, (Sum), 34-46.

Opricovic, S., \& Tzeng, G. H. (2003). Defuzzification within a multicriteria decision model. International Journal of Uncertainty, Fuzziness and Knowledge-Based Systems, 11(05), 635-652.

Carmona, R. (2014). Statistical analysis of financial data in R. New York: Springer.

Ryan, A., \& Lewis, H. (2007). Manufacturing an environmentally friendly PCB using existing industrial processes and equipment. Robotics and Computer-Integrated Manufacturing, 23(6), 720-726.

Sharifi Far, M., Ghobadi, M., \& Ostadi, H. (2015). Effect of U.S dollar rate shocks on tse main indices reaction. ISJ Theoretical \& Applied Science, 2(22), 88-95.

Sugeno, M. and Terano, T. (1997), “A model of learning based on fuzzy information”, Kybernetes, 6(2): 157-166.

Viskanta, T. E. (2012). Abnormal returns. McGraw-Hill.

Tsai, C. Y., \& Chiu, C. C. (2007). A case-based reasoning system for PCB principal process parameter identification. Expert Systems with Applications, 32(4), 1183-1193.

Tsai, C. Y., Chiu, C. C., \& Chen, J. S. (2005). A case-based reasoning system for PCB defect prediction. Expert Systems with Applications, 28(4), 813-822.

Wang, R. T., Ho, C. T. B., \& Oh, K. (2010). Measuring production and marketing efficiency using grey relation analysis and data envelopment analysis. International Journal of Production Research, 48(1), 183-199.

Yu, S., Kim, D., \& Park*, S. (2005). Integer programming approach to the printed circuit board grouping problem. International journal of production research, 43(8), 1667-1684. 